\title{
FORSPAN Model Users Guide
}

T.R. Klett and Ronald R. Charpentier

U.S. Geological Survey Open-File Report 03-354

U. S. Department of the Interior

U.S. Geological Survey 


\section{U. S. Department of the Interior}

Gale A. Norton, Secretary

U.S. Geological Survey

Charles G. Groat, Director

This report is only available on-line at:

http://pubs.usgs.gov/of/2003/ofr-03-354

Any use of trade, product, or firm names is for descriptive purposes only and does not imply endorsement by the U.S. Government.

Published in the Central Region, Denver, Colorado Manuscript approved for publication

Graphics by the author

Edited by Lorna Carter 


\section{Contents}

Abstract

Introduction

Background

Terms and Definitions

Identification and Delineation of Continuous Assessment Units

Supporting Data Required for FORSPAN

Input Data Form

Identification Information

Characteristics of Assessment Unit

The Example

Number of Untested Cells with Potential for Additions to Reserves

1. Total assessment-unit area

2. Area per cell of untested cells having potential for additions to reserves

3. Percentage of total assessment-unit area that is untested

4. Percentage of untested assessment-unit area that has potential for additions to reserves

Minimum Scenario

Maximum Scenario

Modal Value (or Scenario) and Calculated Mean

Total Recovery Per Cell

Average Co-product Ratios for Untested Cells, to Assess Co-products

Selected Ancillary Data for Untested Cells

Allocations of Potential Additions to Reserves 
Conclusions

References Cited

Figures

1 Conventional and continuous accumulations

2 Map of assessment unit with known sweet spot

3 Graphs showing the distribution of EUR's of wells within the assessment unit used to determine the median total recovery per cell

4 Graph showing the distribution of EUR's of wells having total recovery per cell greater than or equal to the minimum and divided into the first-third, the secondthird, and the third-third of wells drilled

A4-1. Components of a triangular distribution

A4-2 Components of two oppositely skewed triangular distributions

A4-3 Components of a lognormal distribution

Appendices

1 Basic input-data form for the FORSPAN model

2 Data worksheet

3 Completed FORSPAN basic input data form

4 Distribution types 


\begin{abstract}
The USGS FORSPAN model is designed for the assessment of continuous accumulations of crude oil, natural gas, and natural gas liquids (collectively called petroleum). Continuous (also called "unconventional") accumulations have large spatial dimensions and lack well defined down-dip petroleum/water contacts. Oil and natural gas therefore are not localized by buoyancy in water in these accumulations. Continuous accumulations include "tight gas reservoirs," coalbed gas, oil and gas in shale, oil and gas in chalk, and shallow biogenic gas.

The FORSPAN model treats a continuous accumulation as a collection of petroleumcontaining cells for assessment purposes. Each cell is capable of producing oil or gas, but the cells may vary significantly from one another in their production (and thus economic) characteristics. The potential additions to reserves from continuous petroleum resources are calculated by statistically combining probability distributions of the estimated number of untested cells having the potential for additions to reserves with the estimated volume of oil and natural gas that each of the untested cells may potentially produce (total recovery). One such statistical method for combination of number of cells with total recovery, used by the USGS, is called ACCESS.
\end{abstract}

\title{
Introduction
}

An accumulation is one or more reservoirs of petroleum (a collective term for crude oil, natural gas, and natural gas liquids) that share a particular trap, charge, and set of reservoir characteristics. For purposes of assessment, an accumulation is treated as a single entity. The USGS identifies two major types of petroleum accumulations based on geology - conventional and continuous (Fig. 1). A conventional accumulation may be an entire field, or only those reservoirs of the field associated with a particular total petroleum system. A continuous accumulation is more extensive and may include several productive areas that (in non-USGS terminology) may be referred to as fields. Conventional accumulations are associated with structural or stratigraphic traps, commonly bounded by a down-dip water contact, and therefore affected by the buoyancy of petroleum in water (Schmoker, 1996; Schmoker, 1999). Continuous accumulations are areally extensive reservoirs of petroleum not necessarily related to conventional structural or stratigraphic traps. These accumulations lack well defined down-dip petroleum/water contacts, and thus are not localized by the buoyancy of oil or natural gas in water (Schmoker, 1996; Schmoker, 1999). Examples of continuous accumulations include "tight gas reservoirs," coalbed gas, oil and gas in shale, oil and gas in chalk, basin-centered gas, and shallow biogenic gas.

To estimate the potential additions to reserves of continuous accumulations, the USGS has developed a model called "FORSPAN" (acronym for FORecast SPAN; Schmoker, 1999). The FORSPAN model treats a continuous accumulation as a collection of petroleum-containing cells for assessment purposes. A cell is a subdivision or area within a continuous accumulation having dimensions related to the drainage areas of wells. Cells are areas that could potentially be drained by one well, although some cells may have had more than one well drilled in them in the past. Thus a cell may contain more than one well. Each cell is capable of producing oil or gas, but the cells may vary significantly from one another in their production (and thus economic) 
characteristics (Schmoker, 1999). The potential additions to reserves from continuous petroleum resources are calculated by statistically combining probability distributions of the estimated number of untested cells having the potential for additions to reserves with the estimated volume of oil and natural gas that each of the untested cells may potentially produce (total recovery). One such statistical method for combination of number of cells with total recovery, used by the USGS, is called ACCESS (acronym for Analytic Cell-based Continuous Energy Spreadsheet System) and is described by Crovelli (2000).

Traditionally, continuous accumulations had been assessed by a volumetric approach. Basic geologic characteristics (such as area, thickness, and porosity of reservoirs) were treated as probabilistic variables to calculate in-place volumes of resource. These variables all had associated uncertainties and were correlated with one another in ways that were poorly understood and very difficult to model.

According to Schmoker (2003), the FORSPAN model is based on the production performance of reservoirs, as empirically shown by wells. In this method, estimates of in-place oil or gas volumes are not developed. Instead, production data are used for forecasts of potential additions to reserves. Such reservoir-performance assessment models are particularly well suited to continuous accumulations that are already partially developed. The wells themselves serve as comprehensive analog computers that evaluate and weight all relevant reservoir parameters (such as thickness, water saturation, permeability, and porosity). In effect, production data are used to empirically provide the product of petroleum-in-place and recovery factor. Lacking sufficient drilling and production data, the assessor must draw upon information from analog accumulations.

This paper describes the implementation of the FORSPAN assessment model by presenting a realistic example. The example provides guidelines for completing the FORSPAN model inputdata form (appendix 1) (Schmoker, 1999). The assessment of each continuous accumulation requires knowledge of a set of factors, including geologic conditions and exploration and production history. The example is generic and does not address all possibilities, but it does, however, address the more important factors required for completing the input-data form.

At various locations in the text, a set of questions that might help the assessor consider the type of input needed and its geologic or exploration provenance. Moreover, these questions, or ones like them, are frequently discussed in the assessment meetings.

Appendix two contains a Microsoft Excel spreadsheet program with encoded equations that are given in the text. This spreadsheet will expedite the calculations required for completing the basic input-data form.

\section{Background}

In order to organize, evaluate, and delineate areas to assess, a hierarchical scheme of geographic and geologic units was developed (Klett and others, 1997). This scheme consists of regions, geologic provinces, total petroleum systems, and assessment units. Regions serve as organizational units and geologic provinces are used as prioritization tools. Total petroleum 
systems are geologic entities that include the rocks related by the generation from a pod or related pods of source rock and the subsequent migration and trapping of the resultant fluids. Undiscovered petroleum resources are assessed within subsets of the total petroleum systems called assessment units.

A geologic province is an area having characteristic dimensions of hundreds of kilometers that encompasses a natural geologic entity (for example, a sedimentary basin, thrust belt, or accreted terrane) or some combination of contiguous geologic entities. Each geologic province is a spatial entity with common geologic attributes. Province boundaries are drawn as much as possible along natural geologic boundaries, although in some places they may be located at boundaries that have technologic or political significance (for example, along specific waterdepth contours in the open oceans). Total petroleum systems and assessment units are delineated for each geologic province that is assessed. Boundaries of total petroleum systems and assessment units do not have to be entirely contained within a geologic province.

The total petroleum system is a mappable entity encompassing genetically related petroleum that occurs in seeps, shows, and accumulations (discovered or undiscovered) that have been generated by a pod or by closely related pods of mature source rock, together with the essential mappable geologic elements (source, reservoir, seal, and overburden rocks) that controlled fundamental processes of generation, migration, entrapment, and preservation of petroleum. Particular emphasis is placed on the genetic similarities of petroleum fluids within total petroleum systems.

An assessment unit is a mappable part of a total petroleum system in which discovered and undiscovered oil and gas accumulations constitute a single relatively homogeneous population for which the methodology of resource assessment is applicable. A total petroleum system might equate to a single assessment unit. If necessary, a total petroleum system may be subdivided into two or more assessment units such that each assessment unit is sufficiently homogeneous in terms of geology, exploration considerations, and risk to assess individually.

A numeric code identifies each region, province, total petroleum system, and assessment unit. The criteria for assigning codes are uniform throughout the project and throughout all publications of the project. An example of the numeric codes used in this study is:

$\begin{array}{lll}\text { Unit } & \text { Name } & \text { Code } \\ \text { Region } & \text { North America } & \mathbf{5} \\ \text { Province } & \text { Southwestern Wyoming } & \mathbf{5 0 3 7} \\ \text { Total Petroleum Systems } & \text { Mesaverde } & 503705 \\ \text { Assessment Units } & \text { Mesaverde Conventional Oil and Gas } & 50370501 \\ & \text { Almond Continuous Gas } & 503705 \mathbf{6 1} \\ & \text { Mesaverde Coalbed Gas } & 50370581\end{array}$

Assessment-unit codes ending with 01 to 59 indicate conventional accumulations; those ending with 61 to 79 indicate continuous oil or gas accumulations; those ending with 81 to 99 indicate continuous coalbed gas accumulations. No assessment-unit codes end with 00 . 


\section{Terms and Definitions}

Selected terms of particular importance to the USGS assessment of undiscovered resources in total petroleum systems are defined here. The definitions are intended to be generally explanatory rather than strictly technical.

Accumulation: One or more reservoirs of petroleum that share a particular trap, charge, and set of reservoir characteristics. For purposes of assessment, an accumulation is treated as a single entity. An accumulation may encompass several fields or equate to a single field or reservoir; alternatively a field may equate to a one or several accumulations. The USGS identifies two major types of petroleum accumulations based on geology - conventional and continuous. A conventional accumulation may be an entire field, or only those reservoirs of the field associated with a particular total petroleum system. A continuous accumulation is more extensive and may include several productive areas that (in non-USGS terminology) may be referred to as fields.

Assessment Unit: A mappable part of a total petroleum system in which discovered and undiscovered oil and gas accumulations constitute a single relatively homogeneous population for which the methodology of resource assessment is applicable. An assessment unit might equate to a total petroleum system, but total petroleum systems may be subdivided into two or more assessment units such that each assessment unit is sufficiently homogeneous in terms of geology, exploration considerations, accessibility, and risk to be assessed individually. An assessment unit may be identified as conventional if it contains conventional accumulations or as continuous if it contains a continuous accumulation.

Assessment Unit Probability: The assessment unit probability, expressed as a decimal fraction, represents the likelihood that, in an assessment unit, at least one untested cell of at least a defined minimum total recoverable volume exists that has the potential for its volume to be added to proved reserves in a given time frame. The assessment unit probability is the product of the probabilities of three geologic attributes (charge, rocks, and timing).

Barrels of Oil Equivalent (BOE): A unit of petroleum volume in which the gas portion is expressed in terms of its energy equivalent in barrels of oil. For this assessment, 6,000 cubic feet of gas equals 1 barrel of oil equivalent (BOE).

Cell: A subdivision or area within a continuous accumulation having dimensions related to the drainage areas of wells (not to be confused with finite-element cells as used in reservoir modeling). Cells are areas that could potentially be drained by one well, although some cells may have had more than one well drilled in them in the past. Thus a cell may contain more than one well. For cells, the potential recoverable oil and natural gas volumes are called total recoverable volumes. For wells, these volumes are called estimated ultimate recovery (EUR). Two types of cells are recognized: tested cells, those evaluated by drilling, and untested cells. Tested cells are categorized as productive, having at least one well with reported production, and nonproductive, evaluated with drilling but where none of the wells have reported production. Untested cells have not been evaluated by wells. 
Composite Total Petroleum System: A mappable entity encompassing all or a portion of two or more total petroleum systems. A composite total petroleum system may be defined when accumulations within an assessment unit are charged by more than one source rock. Composite total petroleum systems may also be defined in cases where field productions cannot be disaggregated into production for reservoirs charged by separate source rocks.

Continuous Accumulation: An accumulation consisting of areally extensive reservoirs of petroleum not necessarily related to conventional structural or stratigraphic traps. These accumulations lack well-defined down-dip petroleum/water contacts, and thus are not localized by the buoyancy of oil or natural gas in water.

Conventional Accumulation: An accumulation associated with structural or stratigraphic traps, commonly bounded by a down-dip water contact, and therefore affected by the buoyancy of petroleum in water.

Cumulative Petroleum Production: Reported volume of petroleum that has been produced up to some given date. Cumulative oil, cumulative gas, and cumulative production are sometimes used as similar terms.

Estimated Ultimate Recovery (EUR): The total expected recoverable volume of oil, gas, and natural gas liquids produced from a well under economic and engineering conditions likely to exist within the forecast span. For cells, the equivalent term is total recovery.

Field: An area consisting of a single reservoir or multiple reservoirs of petroleum, all grouped on, or related to, a single geological structural and (or) stratigraphic feature. Individual reservoirs in a single field may be separated vertically by impervious strata or laterally by local geologic barriers (American Petroleum Institute, 1995). When projected to the surface, the reservoir(s) within the field form a contiguous area that can be circumscribed.

Forecast Span: A specified future time span in which petroleum accumulations have the potential to provide additions to reserves. The forecast span affects (1) the minimum undiscovered conventional accumulation size or minimum total recovery per cell, (2) the number of years in the future that reserve growth is estimated, (3) economic assessments, and (4) the accumulations that are chosen to be considered in this assessment .

Gas to Oil Ratio (GOR): Ratio of gas to oil (in cubic feet/barrel) in an accumulation. In USGS assessments, GOR is calculated using known gas and oil volumes at surface conditions.

Liquids to Gas Ratio (LGR): Ratio of total petroleum liquids (including oil, condensate, and natural gas liquids) to gas (in barrels/million cubic feet) in a gas accumulation. The LGR is calculated using known petroleum liquids and gas volumes at surface conditions. This ratio is used to assess the liquid co-products associated with undiscovered gas in gas accumulations.

Minimum Total Recovery per Cell: The smallest total recovery per cell (volume of oil or gas) considered in the assessment process for continuous-type accumulations. 
Sweet Spot: An area within a continuous accumulation where production characteristics are relatively more favorable.

Total Petroleum System: A mappable entity encompassing genetically related petroleum that occurs in seeps, shows, and accumulations (discovered or undiscovered) that have been generated by a pod or by closely related pods of mature source rock, together with the essential mappable geologic elements (source, reservoir, seal, and overburden rocks) that controlled fundamental processes of generation, migration, entrapment, and preservation of petroleum.

Total Recovery: The total expected recoverable volumes of oil, gas, and natural gas liquids that could be produced from a cell under economic and engineering conditions likely to exist within the forecast span. For wells, the equivalent term is estimated ultimate recovery (EUR).

USGS Assessed Petroleum Volumes: The quantities of oil, gas, and natural gas liquids that have the potential to be added to reserves within some future time frame. The USGS assessed petroleum volumes include those from undiscovered conventional accumulations or development of continuous accumulations, whose sizes are greater than or equal to the stated minimum accumulation size or total recovery per cell, and from the reserve growth of fields already discovered.

\section{Identification and Delineation of Continuous Assessment Units}

Proper identification and delineation of a continuous assessment unit that is homogeneous in terms of geology and exploration/discovery history is essential to the FORSPAN assessment model. The following questions can be used to help the assessor identify and delineate continuous assessments.

Questions to be addressed:

- Are petroleum/water contacts present anywhere in the assessment unit? This is the most indicative criteria for a continuous accumulation. Overpressure, high vitrinite reflectance values, lack of reported produced water, and low permeability alone are not sufficient criteria.

- Is the oil or natural gas self-sourced?

- Is the oil or natural gas ubiquitous?

- Does the reservoir rock have low-matrix permeability?

- Are the boundaries of the assessment unit and sweet spot(s) properly defined (for example, are the boundaries defined by outcrop, lithofacies change, thermal maturity, depth)?

- Can the factors that define the assessment unit and sweet spot(s) boundaries be documented? 
Continuous accumulations generally do not have sharp oil-water or gas-water contacts. They may, however, have vertically or laterally extensive, gradational contacts that would classify these types of accumulations somewhere in a transition zone between strictly continuous and strictly conventional accumulations. Continuous accumulations are commonly self-sourced, have ubiquitous petroleum, and commonly have low matrix permeability. Overpressure, high vitrinite reflectance values, or low matrix permeability alone are not sufficient criteria for the identification of a continuous accumulation. Similarly, the lack of reported produced water is insufficient evidence for the existence of a continuous accumulation. Coalbed gas accumulations, for example, often produce large volumes of water.

In most areas, sweet spots cannot be delineated and mapped. Their existence and areas can only be estimated.

\section{Supporting Data Required for FORSPAN}

Essential geologic, geographic, and engineering data are required prior to using the FORSPAN model. Once collected and compiled, these data are used in conjunction with a set of equations (numbered throughout the form) to provide estimates of the number and total recovery of cells with undiscovered petroleum potential within the assessment unit, which in turn, are used to calculate the potential additions to reserves. The data and equations required for the completion of the FORSPAN model basic input data form are given in the spreadsheet in appendix 2.

Two databases from IHS Energy Group (2002a, b), the PI/Dwights Plus US Well Data and PI/Dwights Plus US Production Data, are used extensively in the ongoing U.S. Geological Survey National Oil and Gas Assessment. Additional field and reservoir data come from NRG Associates (2002).

FORSPAN requires the estimated ultimate recovery (EUR) of oil or natural gas from wells or analog wells to aid in the estimation of total recovery per cell. A cell is a subdivision or area within an assessment unit having dimensions related to the drainage areas of wells (Schmoker, 1999). Because cumulative production is the most common volume reported for wells, EUR's must be estimated from these volumes by modeling. For the NOGA study, cumulative production data is obtained from the IHS Energy Group's PI/Dwights Plus US Well Production database.

The basic historical information on which the assessment is made is well-level information. In some cases, wells have been drilled at spacing close enough to interfere with one another. If well-level EUR values and spacings were extrapolated into undrilled areas, there is the possibility that the resource would be underestimated (because undrained areas remained between wells) or overestimated (because interfering wells double-counted the same resource).

Because of the potential problems with pure well information, the concept of cells was developed. Cells have dimensions that relate to the actual drainage areas of wells. Thus the total 
recoveries from cells combined with the number of cells in an assessment unit should yield an estimate of volume of resource that is self-consistent.

The actual drainage areas of wells vary within an assessment unit. The difference in drainage area probably is the most important cause of the difference in EUR, which often ranges two orders of magnitude in an assessment unit. Thus drilling practice that uses a set well spacing may leave some resource undeveloped in areas between wells at the same time as some pairs of well interfere with one another.

Once calculated, the overall distribution of EUR's that tested the assessment-unit interval, as well as the distributions by discovery-history segments, are derived. These distributions serve as a guide for estimating total recovery per cell and the selection of a minimum recovery, below which cells are considered unsuccessful.

\section{Input-Data Form}

This section corresponds to the completed data-input form shown in appendix 3. The form consists of seven sections, which are:

- Identification Information

- Characteristics of Assessment Unit

- Number of Untested Cells with Potential for Additions to Reserves

- Total Recovery per Cell

- Average Co-product Ratios for Untested Cells

- Selected Ancillary Data for Untested Cells

- Allocations of Potential Additions to Reserves (to States, General Land Ownerships, Federal Land Subdivisions, and Ecosystems)

Identification information supplies the data necessary for record keeping and assessment organization. Statistical combination of the minimum total recovery per cell and geologic probabilities (from Characteristics of Assessment Unit), number of untested cells, total recovery per cell, and co-product ratios yields probability distributions for quantities of petroleum having the potential to be added to reserves. Selected ancillary data provide a set of information (not used directly in assessment calculations) that is required for economic and environmental analyses. Allocation percentages allow the apportionment of assessed potential additions to reserves to various land entities of interest within the assessment unit.

\section{Identification Information}

The first section of the data form is for identification information and notes relevant to the assessment (Schmoker, 1999). The hierarchy of codes for assessment-related areas that range downward in size from region and geologic province to the total petroleum system and assessment unit is recorded in this section, along with the formal names for each. 


\section{Characteristics of Assessment Unit}

Spatial analysis using geographic information systems (GIS) and volumetric analysis using petroleum-engineering models are required for completing the first parts of the FORSPAN Input Data Form. First, boundaries of total petroleum systems and included assessment units should be properly drawn and digitized. Next, the digital total petroleum system and assessment unit boundaries, along with the locations and types of all wells from the IHS Energy Group's PI/Dwights databases, are used to select and create a list of those wells that exist within the assessment unit boundaries. This list is then used to select all of the wells that presumably tested the reservoir intervals of cells within the assessment unit. The resulting list of wells is used to determine the total number of tested cells in the assessment unit. A list of wells that produce from the reservoir intervals is then derived. The production data for these wells are used to model the EUR's of wells in the assessment unit.

Questions to be addressed:

- What is the primary commodity in the assessment unit, oil or natural gas?

- Can undiscovered co-products be accurately estimated using co-product ratios? Otherwise, two input-data forms must be used.

- What has been the drilling history; where has drilling occurred?

- Have geologic factors influenced the drilling history?

- Have other factors such as lease availability and economics influenced the drilling history?

Two types of cells are recognized: (1) tested cells, those evaluated by drilling, and (2) untested cells. Tested cells are categorized as productive, having at least one well with reported production, or nonproductive, evaluated with drilling but where none of the wells have reported production. Untested cells have not been evaluated by wells. Tested cells include those where hydrocarbon is produced, production is demonstrated by formation tests (that is, drill-stem tests), evidence of hydrocarbon presence is observed on well logs or in cores, and hydrocarbon shows are observed on mud logs in reservoir intervals of the continuous assessment unit within wells penetrating the cell. 
Questions to be addressed:

- What constitutes a test of the interval? In many cases, all penetrations can be considered tests. Shows must also be considered.

- Should additional tested cells be considered? Not all wells are reported in the databases, particularly in areas of older production.

- Should a proportion of the penetrations be considered tests?

- Is there a date before which penetrations were unlikely to test the interval?

- In choosing a minimum estimated ultimate recovery (EUR) to identify successful wells that tested the interval, are many wells dismissed as having a low EUR?

- Have wells with low EURs been classified as dry holes?

- Is the minimum total recovery per cell the same for other assessment units in the total petroleum system?

\section{The Example}

The example used in the present report is that of a continuous basin-centered gas accumulation. Three steps are involved for completion of the form: (1) obtain necessary geologic and engineering information, (2) properly define the assessment units in terms of spatial location and geology, and (3) complete the basic input-data form for the assessment. A schematic map of the assessment unit with sweet spot used in this example is shown in figure 2 .

The assessment unit used in this example has the following characteristics:

- The assessment unit is a continuous, basin-centered gas accumulation.

- Gas is produced throughout the assessment unit, but mostly from one sweet spot in the western portion (fig. 2).

- Total assessment-unit area is approximately 1,500,000 acres.

- Area outside the sweet spot is approximately 1,000,000 acres.

- Area outside the sweet spot contains 100 wells at 240 -acre spacing with $77 \%$ classified as dry holes.

- Sweet spot area is approximately 500,000 acres.

- Sweet spot contains 2,400 wells at 160-acre spacing with 5\% classified as dry holes.

The FORSPAN model requires cell information, but typically, wells are used as surrogates for cells. The historic EUR distributions of wells within the assessment unit are required to 
evaluate the total recovery per cell. Wells that are classified as not dry may or may not have EUR's exceeding the minimum, therefore these wells may or may not be considered successful.

Historically in some areas, wells were drilled with spacings less than the average drainage area. This type of drilling density results in the number of tested cells to be less than the number of wells that tested the accumulation. Additionally, low EUR's from these wells would incorrectly indicate low total recoverable volumes of untested cells. Typically, expected drainage areas are less than actual drilled spacings and such correction is not necessary.

In this example, a total of 10,000 wells have been drilled in the area of the assessment unit, but most target shallower formations. Out of these wells, only 2,500 actually tested the interval upon which the assessment unit is defined. Out of these 2,500 wells, 197 were classified as dry holes in the database. For this example assessment unit,

$(1-(197$ dry wells / 2,500 total wells that tested $)) * 100=$ $92 \%$ wells that tested are not dry

A minimum total recovery per cell is chosen, below which cells are considered unsuccessful. All wells with EUR below this value are considered unsuccessful, as are all wells that were classified as dry. Too high a minimum would result in elimination of many cells that have already produced. Therefore, the original EUR distribution should not be reduced more than about 15 to 20 percent. Having a consistent minimum total recovery per cell in all assessment units within a province or other area helps make the comparisons between assessment units easier.

A minimum EUR of 0.02 billion cubic feet of gas (bcfg) is selected for a successful well in this example, and is used for the total recovery per cell (fig. $3 A, B$ ). Based on this cutoff, about $2 \%$, or 46 wells, of the remaining 2,303 non-dry wells are subtracted for being unsuccessful, that is, less than the required minimum total recovery. Therefore, only about 2,257 wells, considered to be successful, tested the producing interval of the assessment unit. The historical success ratio has been

$(2,257$ successful wells that tested / 2,500 total wells that tested $) * 100=$ $90 \%$ wells that tested are successful

The ratio of the number of successful wells per total number of tested wells for the entire assessment unit, for sweet spots, and for areas outside sweet spots should be noted. These ratios are used in subsequent calculations.

Because more than 24 cells (as determined from wells; wells are typically used as surrogates for cells) greater than or equal to the minimum total recovery exist, the assessment unit is considered as established. The following information is recorded on the input-data form: 
Assessment-unit type: Oil ( $<20,000 \mathrm{cfg} / \mathrm{bo})$ or Gas $(\geq 20,000 \mathrm{cfg} / \mathrm{bo})$, incl. disc. \& pot. additions What is the minimum total recovery per cell? $0.02 \quad$ (mmbo for oil A.U.; bcfg for gas A.U.)

The group of tested cells having total recovery per cell greater than or equal to the minimum can be divided into the first-third drilled, the second-third drilled, and the third-third drilled (or the first-half and second-half drilled, if data points are few). Graphs showing the distributions of EUR's for each of these discovery-history segments (fig. 4) are used to determine the median total recovery per cell.

Changes in completion practice and production characteristics result in change through time in the distribution of EUR's. The FORSPAN model input-data form records changes in the median values of the EUR distributions through time as a function of the first, second, and third third of producing wells drilled (see section on Total Recovery per Cell). This historic record is used to aid in the estimation of EUR's of wells drilled in the future. Commonly, the median EUR increases early in the exploration history (between the first- and second thirds), reflecting the operator's attempt to achieve the most efficient completion and production practices for the given area. Decreasing median values typically follow, between the second- and third-third, as the most productive wells were discovered earlier. Decreases in median EUR with time reflect the early identification of sweet spots and later drilling further from the areas of best production characteristics.

The following information is recorded on the input-data form:

Median total recovery per cell (for cells $\geq \min$.): (mmbo for oil A.U.; bcfg for gas A.U.)

$\begin{array}{lllll}1 \text { st 3rd discovered } & 0.31 & \text { 2nd 3rd } \quad 0.3 & \text { 3rd 3rd } \quad 0.22\end{array}$

Assessment-unit probabilities are then estimated. Three geologic risking elements (attributes), charge, rocks, and timing, address the question of the probability of occurrence of at least one cell of minimum total recovery somewhere in the assessment unit that has the potential to be added to reserves. Each risking element applies to the assessment unit as a whole, and does not equate to the percentage of the assessment unit that might be unfavorable in terms of geology.

The risking structure is based on the assumption that assessment units are reasonably homogeneous in terms of charge, rocks, and timing. For example, favorable charge should not occur only in the western half of an assessment unit and favorable rocks only in the eastern half. Such a situation would suggest that the assessment unit is too large and should be redefined and perhaps subdivided.

In almost all cases, the assessment-unit probability is 1.0. Because most assessment units consist of thousands to hundreds of thousands of cells and because specified minimum total recoveries are set very low, the risk of an individual cell being unsuccessful (containing less than the specified minimum total recovery) is usually relatively low. 
For this example, the existence of at least one more untested cell of minimum total recovery is assumed. Therefore, the probability of occurrence with respect to charge, rocks, and geologic timing is one, and is recorded on the input-data form as such:

Assessment-Unit Probabilities:

Attribute

Probability of occurrence $(0-1.0)$

1. CHARGE: Adequate petroleum charge for an untested cell with total recovery $\geq$ minimum.

2. ROCKS: Adequate reservoirs, traps, seals for an untested cell with total recovery $\geq$ minimum.

3. TIMING: Favorable geologic timing for an untested cell with total recovery $\geq$ minimum.

$\begin{array}{r}1.0 \\ \hline 1.0 \\ \hline 1.0 \\ \hline\end{array}$

Assessment-Unit GEOLOGIC Probability (Product of 1, 2, and 3):

\section{Number of Untested Cells with Potential for Additions to Reserves}

The USGS has adopted a 30-year forecast span for its assessments of petroleum resources. The goal of using the FORSPAN assessment model is to estimate volumes of petroleum having the potential to be added to reserves in the next few decades. This section explains the estimation processes for four variables that are used to obtain the number of untested cells with potential for additions to reserves.

\section{Total assessment-unit area:}

The variable estimated in line 1 is the area of the assessment unit. The boundaries of this area may be fixed or may show some amount of uncertainty. Boundaries based on mapped geologic characteristics (such as outcrop, depth, or degree of thermal maturation) can have varying amounts of uncertainty. Outcrop boundaries are usually known with better precision than a maturation boundary based on a few vitrinite reflectance values. In some cases, particularly where two continuous assessment units adjoin, the boundary is fixed in order to avoid either overlapping of assessment units or negative correlations between their resource estimates. In the case of a continuous assessment unit surrounded by other continuous assessment units, it is possible that all the boundaries could be fixed and thus that no uncertainty would be expressed in the line 1 input.

Questions to be addressed:

- What uncertainty exists for the factors that define the assessment unit?

- How does the uncertainty affect the area of the assessment unit?

- Are portions of the assessment-unit boundary common with neighboring assessment units, and if so, are the neighboring assessment units conventional or continuous?

Because this example assessment unit is continuous and all of the neighboring assessment units are not continuous, its extent is somewhat uncertain. Based on the geological characteristics of the assessment unit (extent of mature source rock, reservoir rocks, potential traps, and so on), the assessment-unit area could be as small as 1,200,000 acres or as large as 
$1,700,000$ acres. For this example, 1,500,000 acres is chosen for the modal area of the assessment unit. The following information is recorded on the input-data form:

1. Total assessment-unit area (acres): (uncertainty of a fixed value)

calculated mean $\underline{1,466,667}$ minimum $\underline{1,200,000}$ mode $\underline{1,500,000}$ maximum $\underline{1,700,000}$

The calculated mean of the total assessment-unit area is approximately 1,470,000 acres. This mean is based on use of a triangular distribution. Although the input form does not specify use of a particular distribution type, current USGS practice is to use triangular distributions for all the variables on the FORSPAN form except for the distribution of total recovery per cell, for which a truncated shifted lognormal distribution is used. Descriptions of these distribution types can be found in appendix 4.

The range in the assessment-unit area should not reflect the error in GIS delineation (which is minimal), but should reflect uncertainty in the geologic extent of the assessment unit. If the assessment unit boundaries are fixed or if all surrounding assessment units are continuous, then an assessment-unit area range cannot be specified. In this case, only a single number is entered for the mean, minimum, mode, and maximum.

\section{Area per cell of untested cells having potential for additions to reserves:}

The area per cell is equivalent to the drainage area of a well. The drainage areas of wells and areas per cells can be approximated by analysis of current well spacing and production characteristics. Wells are typically spaced such as to maximize recovery and increase production rate and are not spaced to demonstrate drainage area. The area per cell is the area that could potentially be drained by one well. This drainage area is not uniform and therefore represented by a distribution.

Questions to be addressed:

- What are the actual drainage areas of wells in the assessment unit?

- How does the drainage areas of wells differ from the current well spacing?

- Are there indications that the current spacing is less or greater than the drainage areas?

- How does the well spacing in sweet spots compare to well spacing(s) in areas outside sweet spots?

For this example, the current well spacing in the sweet spot is 160 acres. Outside of the sweet spot, well spacing is typically 240 acres. Based on reservoir-engineering calculations, some wells may drain as little as 10 acres or as much as 240 acres. Therefore, 10-acres is used for the minimum and 240 acres for the maximum. Most of the wells are expected to drain areas closer to the minimum than to the maximum, so the mode was set at 20 acres. 
Assuming a triangular distribution, the mean area is approximately 90 acres. There is some uncertainty about this value, however. For an individual cell, the drainage area may be as small as 10 acres or as high as 240 acres. The average value of thousands of cells, however, is not likely to be as low as 10 acres or as high as 240 acres. For this example, the minimum and maximum values for the uncertainty of the mean area are 70 and 100 acres, respectively.

Based on these assumptions, the following information is recorded on the input-data form:

2. Area per cell of untested cells having potential additions to reserves (acres):(values are inherently variable)

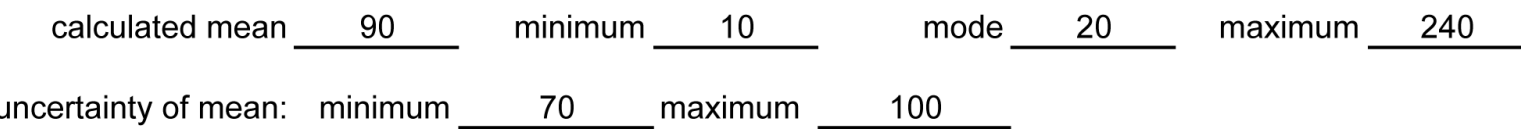

\section{Percentage of total assessment-unit area that is untested:}

To estimate the percentage of the assessment unit that is untested, it is easiest to first consider the percentage of the assessment unit that has been tested. The following calculations show how values consistent with those of lines 1 and 2 can be derived.

The calculated mean total assessment-unit area from line 1 is 1,470,000 acres (rounded). From the Characteristics of Assessment Unit section, 2,500 cells were tested. Therefore, the mean percentage of cells that had been tested is

$((2,500$ tested cells $* 90$ acres per cell $) / 1,470,000$ acres in the assessment unit $) * 100=$

$15.3 \%$ of total assessment-unit area that is tested

and the untested area is

$100 \%-15.3 \%$ of total assessment-unit area that is tested $=$

$84.7 \%$ of total assessment-unit area that is untested

This $84.7 \%$ is considered the mean of the percent of the untested assessment-unit area. The minimum percentage of the total assessment-unit area that is untested (and the maximum percentage that is tested) would occur if the assessment-unit area was smaller than expected and area per cell was larger than expected. In this example, the minimum assessment-unit area (from line 1) is 1,200,000 acres. The maximum area per cell is estimated to be 240 acres, but it is unlikely that all of the cell areas would be that large. For the input on line 2, it was estimated that the largest the average of the cell areas could get is 100 acres. The minimum percentage of total assessment-unit area that is untested is calculated by

$((2,500$ tested cells $* 100$ acres per cell $) / 1,200,000$ acres in the assessment unit $) * 100=$ $20.8 \%$ of total assessment-unit area that is tested

and 
$100 \%-20.8 \%$ of total assessment-unit area that is tested $=$

$79.2 \%$ of total assessment-unit area that is untested

Following the same logic as for the previous calculation, the maximum percentage of total assessment-unit area that is untested (and the minimum percentage of total assessment-unit area that is tested) would occur if the assessment-unit area was larger than expected and area per cell was smaller than expected. In this example, the maximum assessment-unit area (from line 1) is $1,700,000$ acres. The minimum area per cell is estimated to be 10 acres, but it is unlikely that all of the cell areas would be that small. For the input on line 2, it was estimated that the smallest the average cell area could get is 70 acres. The minimum percentage of total assessment-unit area that is untested is calculated by

$((2,500$ tested cells $* 70$ acres per cell $) / 1,700,000$ acres in the assessment unit $) * 100=$ $10.3 \%$ of total assessment-unit area that is tested

and

$100 \%-10.3 \%$ of total assessment-unit area that is tested $=$

$89.7 \%$ of total assessment-unit area that is untested

Based on these calculations and assumptions, the information recorded on the input-data form is:

3. Percentage of total assessment-unit area that is untested (\%): (uncertainty of a fixed value)

calculated mean $\quad 84.7 \quad$ minimum $\quad 79.2 \quad$ mode $\quad 85.2 \quad$ maximum $\quad 89.7$

The mode can be calculated given the minimum, mean, and maximum (see appendix 4).

\section{Percentage of untested assessment-unit area that has potential for additions to reserves:}

This variable reflects the areal extent of sweet spots, both known and hypothesized. The input can be developed using three geologic scenarios that describe the minimum, most likely, and maximum extents. A common approach to estimate the parameters entered on line 4 is to develop scenarios for both the minimum and the maximum case. The modal case is then either developed as a third scenario or interpolated as being more or less like the minimum and maximum scenarios.

There are many ways to estimate the percentage of untested assessment-unit area that has potential for additions to reserves, including visual inspection of maps combined with geologic knowledge of the area, and calculation. Regardless of the method for estimating this variable, there must be a geologic basis for the estimate. The geologic evidence in support of the estimates should be documented and would include mapped geologic features, locations of anticipated sweet spots, and uncertainty of future success ratios.

Line 4 is used to quantify the spatial distribution of geologic characteristics that control petroleum-resource recovery. Resource assessment is dependent on a geologic model that explains the areal distribution of sweet spots. The area containing sweet spots may not be 
mappable within the assessment-unit boundary, but the area percent may be estimated probabilistically and recorded on line 4.

The following example shows how a model of sweet spot extent is constrained by other information on the input form to assure reasonable values for line 4. Typically, the preceding three variables ((1) total assessment-unit area, (2) area per cell of untested cells having potential for additions to reserves, and (3) percentage of total assessment-unit area that is untested) are used to constrain the parameters for this fourth variable (the percentage of untested assessmentunit area that has potential for additions to reserves).

The percentage of untested assessment-unit area that has the potential for additions to reserves in the given forecast span is estimated by considering known sweet spots separately from areas outside the known sweet spots. In continuous assessment units containing known sweet spots, the percentage of untested assessment-unit area that has potential for additions to reserves exists as both areas subject to infill drilling and expansion within known sweet spots, as well as some areas outside known sweet spots favorable for occurrence of oil or natural gas.

Questions to be addressed:

- How have success ratios of wells changed through time, both within and outside the sweet spots?

- Are the historical success ratios of wells both within and outside of sweet spots expected to be the same in the future?

- Will the success ratio of wells in undiscovered sweet spots be similar or different than that for known sweet spots?

- Should the triangular distribution be preferentially skewed to reflect geologic characteristics of the area?

The geologic model in this example is that the sweet spots are controlled by fracture intensity. Past drilling has already identified a sweet spot with higher fracture intensity. The most basic geologic question addressed in line 4 concerns how much of the untested area may also have higher fracture intensity. In this example, between 20 to 75 percent of the area outside the known sweet spot may have greater fracture intensity and thus be additional sweet-spot areas.

The first set of calculations in this section (equations 9 through 18) is used to estimate the minimum value and the second set (equations 19 through 28), the maximum value.

\section{Minimum Scenario}

For this example, the geologic scenario for the minimum percentage of untested area having potential for additions to reserves consists of the sweet spot plus $20 \%$ of the area outside the sweet spot (the latter having a future success ratio of about $65 \%$ ). In this example, about 2,400 wells were drilled at a 160 -acre spacing within the known sweet spot, with a $93 \%$ success ratio. 
Based on reservoir-engineering calculations, the average drainage area of these wells (area per cell) is about 90 acres, the average ranging from 70 to 100 acres. Therefore, some area within the sweet spot could have potential for addition to reserves if infill drilling were to proceed. Since this is the minimum scenario, the untested area within the known sweet spot should be minimized. The maximum average cell size should be used for this calculation (100 acres, from line 2). The tested area within the known sweet spot is

2,400 cells $* 100$ acres per cell $=$

240,000 acres tested in the known sweet spot

and the untested area within the known sweet spot is

500,000 acres in the known sweet spot - 240,000 acres tested in the known sweet spot $=$ 260,000 acres untested in the known sweet spot

Some percentage of cells within the untested area of the known sweet spot will be unsuccessful, that is having total recoveries less than the stated minimum of $0.02 \mathrm{bcfg}$. Knowing that the historical success ratio is $93 \%$ and assuming that the future success will be slightly less, this example uses a success ratio of $90 \%$. Note that the past success ratio was based on the average 160-acre spacing (fig. 2), not at the estimated 100-acre spacing.

260,000 acres untested in the known sweet spot $* 90 \%$ success ratio $=$

234,000 acres untested in the known sweet spot having potential for additions to

reserves

About 1,000,000 acres of the total assessment-unit area remain outside the known sweet spot. For this minimum scenario, the geologist has estimated that only about $20 \%$ of that area could contain sufficiently enhanced fracturing to be in undiscovered sweet spots. Only about 100 wells were drilled outside the known sweet spot, having a success ratio of $21 \%$ (fig. 2 ). This example assumes that undiscovered sweet spots could have success ratios of about $65 \%$. The tested area outside of the known sweet spot is

100 cells $* 100$ acres per cell $=$

10,000 acres tested outside the known sweet spot

and the untested area outside the known sweet spot is

1,000,000 acres outside the known sweet spot $-10,000$ acres tested outside the sweet spot $=$ 990,000 acres untested outside the known sweet spot

Based on geologic knowledge, for this example, the geologist estimated that a minimum of $20 \%$ of this area would contain undiscovered sweet spots, so

990,000 acres untested outside the known sweet spot $* 20 \%=$

198,000 acres untested outside the known sweet spot that may contain

undiscovered sweet spots 
Using a success ratio of $65 \%$,

198,000 acres untested outside the known sweet spot that may contain undiscovered sweet spots * $65 \%=$

128,700 acres untested outside the known sweet spot having potential for additions to reserves

Combining the known and undiscovered sweet spot areas yields

234,000 acres untested in the known sweet spot having potential for additions to reserves (eq. 11) $+128,700$ acres untested outside the known sweet spot having potential for additions to reserves (eq. 15) $=$

362,700 acres untested in the assessment unit having potential for additions to reserves

Recall that the entire untested area of the assessment unit is

260,000 acres untested in the known sweet spot (eq. 10) +990,000 acres untested outside the known sweet spot (eq. 13) =

$1,250,000$ acres untested in the assessment unit

and the minimum percentage of untested assessment-unit area that has the potential for additions to reserves in the given forecast span is

(362,700 acres untested in the assessment unit having potential for additions to reserves (eq. 16) / $1,250,000$ acres untested in the assessment unit (eq. 17)) $* 100=$

$29.0 \%$ of untested assessment-unit area that has the potential for additions to

reserves

\section{Maximum Scenario}

For this example, the geologic scenario for the maximum percentage of untested area having potential for additions to reserves includes the known sweet spot plus $75 \%$ of the area outside the sweet spot. For this scenario, the area outside the known sweet spot is assumed to have a future success ratio of about $90 \%$ (rather than $65 \%$ ). For the maximum value in this example, again, about 2,400 wells were drilled at a 160-acre spacing within the known sweet spot, with a $93 \%$ success ratio. Unlike the minimum scenario, the assumed drainage area of these wells (area per cell) is the minimum of 70 acres, thus, more area exists having potential for addition to reserves from infill drilling. The tested area within the known sweet spot is

2,400 cells $* 70$ acres per cell $=$

168,000 acres tested in the known sweet spot

and the untested area within the known sweet spot is 
500,000 acres in the known sweet spot $-168,000$ acres tested in the known sweet spot $=$ 332,000 acres untested in the known sweet spot

Unlike the success ratio used for the minimum scenario, the maximum scenario will assume a better success ratio than had been experienced historically, about $95 \%$.

332,000 acres untested in the known sweet spot $* 95 \%$ success ratio $=$ 315,400 acres untested in the known sweet spot having potential for additions to reserves

The tested area outside of the known sweet spot is

100 cells $* 70$ acres per cell $=$

7,000 acres tested outside the known sweet spot

and the untested area outside the known sweet spot is

$1,000,000$ acres outside the known sweet spot $-7,000$ acres tested outside the sweet spot $=$ 993,000 acres untested outside the known sweet spot

As for the minimum scenario, about 1,000,000 acres of the total assessment-unit area remain outside the known sweet spot. For the maximum scenario, however, the geologist estimated that about $75 \%$ of that area could contain sufficiently enhanced fracturing to be in undiscovered sweet spots and wells drilled in this area could have a success ratio of $90 \%$. The untested area outside the known sweet spot that may contain undiscovered sweet spots is

993,000 acres untested outside the known sweet spot * 75\% $=$

744,750 acres untested outside the known sweet spot that may contain undiscovered sweet spots

Using a success ratio of $90 \%$,

744,750 acres untested outside the known sweet spot that may contain undiscovered sweet spots * $90 \%=$

670,275 acres untested outside the known sweet spot having potential for additions to reserves

Combining the known and undiscovered sweet spot areas yields

315,400 acres untested in the known sweet spot having potential for additions to reserves (eq. $21)+670,275$ acres untested outside the known sweet spot having potential for additions to reserves (eq. 25) $=$

985,675 acres untested in the assessment unit having potential for additions to reserves

Recall that the entire untested area of the assessment unit is 
332,000 acres untested in the known sweet spot (eq. 20) $+993,000$ acres untested outside the known sweet spot (eq. 23) $=$

$1,325,000$ acres untested in the assessment unit

The maximum percentage of untested assessment-unit area that has the potential for additions to reserves in the given forecast span is

(985,675 acres untested in the assessment unit having potential for additions to reserves (eq. 26) / $1,325,000$ acres untested in the assessment unit (eq. 27)) $* 100=$

$74.4 \%$ of untested assessment-unit area that has the potential for additions to reserves

\section{Modal Value (or Scenario) and Calculated Mean}

The modal value could also be calculated using a scenario, but with different assumptions regarding success ratios and areas that have the potential for additions to reserves (median or average scenarios) (appendix 2). An alternate approach would be to consider the relationship of the modal value to the minimum and maximum values. The mode could be placed closer to the value of the scenario that it is more likely to resemble. Should no geologic evidence constrain the direction or amount of skewness of the estimates, a symmetrical triangular distribution may be assumed. The calculated mean of the distribution should be used to check that the distribution is reasonably consistent with the geologic model and the previously entered input. In this example, the mode was expected to be more like the minimum rather than the maximum. is:

Based on the calculations and assumptions, the information recorded on the input-data form

4. Percentage of untested assessment-unit area that has potential for additions to reserves (\%): ( a necessary criterion is that total recovery per cell $\geq$ minimum; uncertainty of a fixed value)

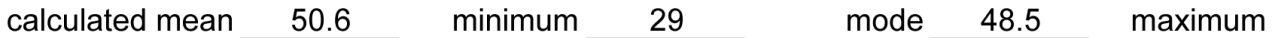
74.4

Geologic bases for estimates: Minimum: Sweet spot having $90 \%$ success ratio plus $20 \%$ of the area outside the sweet spot, having $65 \%$ success ratio. Mode: Calculated using central tendencies of previous variables. Maximum: Sweet spot having $95 \%$ success ratio plus $75 \%$ of the area outside the sweet spot, having $90 \%$ success ratio. Sweet spots are controlled by fracture intensity.

Assuming a triangular distribution, the calculated mean is $50.6 \%$.

\section{Total Recovery per Cell}

The median and maximum total recoveries per cell, of cells yet to be drilled, can be estimated using historical production data as a guide. The minimum total recovery per cell has already been determined and is on the input form in the Characteristics of Assessment Unit section. The remaining input parameters are chosen to represent perceived impacts of future change, such as improved technologies and newly developed geologic and engineering concepts, as well as the 
idea that historical data representing known sweet spots might not be characteristic of all future development.

Graphs showing the distribution of EUR per well for producing wells and showing the EUR distribution divided into discovery-history segments (thirds) are used to determine the parameters for total recovery per cell (figs. 3 and 4). Figure 4 and the data entered in the Characteristics of Assessment Unit section show that the median EUR has decreased with time. For this example, the decrease is interpreted as a result of drilling in areas with less favorable production characteristics, a trend that is expected to continue, so the median for future total recovery per cell is expected to be slightly less than for the third third of drilling. The maximum total recovery per cell is expected to be comparable to that of historical EUR's. No major changes in technology or completion practice are envisioned that would drastically change the future total recoveries per cell from the historical EUR's.

The following information is recorded on the input-data form:

Total recovery per cell for untested cells having potential for additions to reserves:

(values are inherently variable; mmbo for oil A.U.; bcfg for gas A.U.)

calculated mean \begin{tabular}{llll}
0.28 & minimum $\quad 0.02$ & median $\quad 0.2$ & maximum $\quad 2.5$ \\
\hline
\end{tabular}

\section{Average Co-product Ratios for Untested Cells, to Assess Co-products}

For oil accumulations, gas/oil (GOR) ratio and natural gas liquids (NGL)/gas ratio are required; for gas accumulations, total liquids (crude oil, condensate, and NGL)/gas ratio. These ratios should represent the average of the untested co-products and are typically derived from the co-products of known production, analogs, or geochemical studies. The probability distributions for these input variables depict the uncertainty of a fixed but unknown value (the mean), and not the actual range of co-product values among untested cells. The minimum, mode, and maximum represent the distribution for the average co-product ratios, not ranges for the entire population of co-product ratios.

For this example, the assessment unit is identified as a gas assessment unit, so only the liquids/gas ratio is recorded. Historical production data gives a ratio of $10 \mathrm{bliq} / \mathrm{mmcfg}$. There is no reason (such as expectations of deeper drilling) to expect the future liquids/gas ratio to be different in the future. An uncertainty around this mean of plus or minus 50 percent of the mean is a default value for uncertainty of these ratios. The mean liquids/gas ratio could thus be as low as 5 or as high as $10 \mathrm{bliq} / \mathrm{mmcfg}$. (For individual cells, of course, the range could be even wider.) The lines for the other co-product ratios are left blank. Based on production data, the following information is recorded on the data-input form:

Oil assessment unit:

Gas/oil ratio (cfg/bo)

NGL/gas ratio (bngl/mmcfg)

Gas assessment unit:

Liquids/gas ratio (bliq/mmcfg)

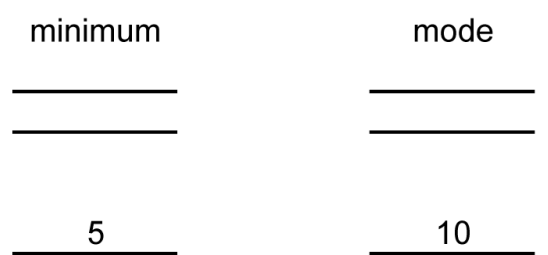

maximum

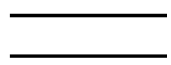

15 


\section{Selected Ancillary Data for Untested Cells}

Data pertaining to oil or natural gas composition, drilling depth, water depth, success ratios , and completion practices are recorded for economic and environmental analyses of assessment results. These data do not contribute directly to volumetric calculations. Unlike the parameters recorded for the range of average values for co-product ratios, the parameters recorded for the composition and depth data represent the range of values for the entire population among untested cells. Thus in this example, an individual cell may have a gas heating value as low as $750 \mathrm{BTU}$ or as high as $1,700 \mathrm{BTU}$.

In this example, the assessment unit is identified as a gas assessment unit, so only gas data are recorded. The lines for oil assessment unit are left blank. In this example, there is no basis for using values different than those from historical production. If, however, future drilling were expected to be at greater depths, that might be reason to modify some of these values. Based on production data, the following information is recorded on the data-input form:

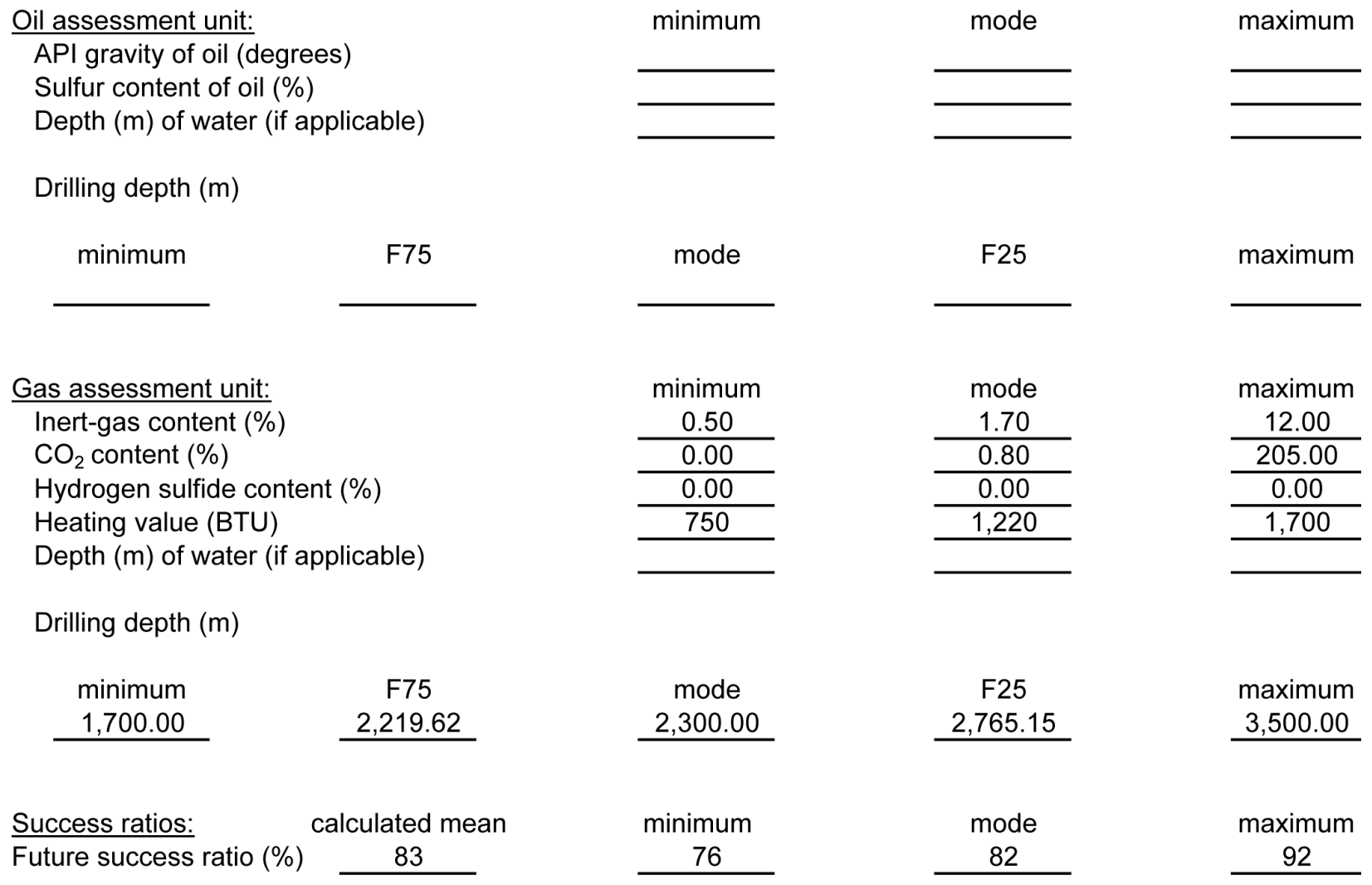

Historic success ratio, tested cells (\%) 90

Completion practices:

1. Typical well-completion practices (conventional, open hole, open cavity, other)

2. Fraction of wells drilled that are typically stimulated

3. Predominant type of stimulation (none, frac, acid, other)

4. Fraction of wells drilled that are horizontal

\begin{tabular}{c}
$\frac{\frac{\text { conventional }}{0.5}}{\mathrm{frac}}$ \\
\hline 0 \\
\hline
\end{tabular}


The success ratios shown on the basic input-data form are for the entire assessment unit and thus do not exactly match those used in the calculations above.

\section{Allocations of Potential Additions to Reserves}

Resource allocations may be made to a number of land parcels (appendix 1), such as (1) countries, geologic provinces, and States (total equals 100 percent); (2) general land ownership parcels, such as Federal lands, tribal lands, private lands, State-owned lands, and offshore areas (total equals 100 percent); (3) categories of Federal lands such as wilderness areas, national forests, and national parks (total equals percentage of Federal lands given in 2); and (4) ecosystem regions (the total percentage of ecosystem allocations equals onshore percentage). The NOGA project uses ecoregions of the lower 48 United States as described by Bailey (1995). Allocations can be based on surface ownership, mineral ownership, or both. The volume percent of assessed resources allocated to an entity does not necessarily equal the area percent of that entity because the areas covered by some land entities may have a higher concentration of resource than others (Schmoker, 1999).

The data form allows for allocation percentages to be recorded as three fractiles $\left(\mathrm{F}_{100}, \mathrm{~F}_{50}\right.$, and $\mathrm{F}_{0}$ ), representing the uncertainty of a fixed but unknown value. A three-fractile input is best suited to the case where an allocation is made to a single land entity (such as a national park) within the assessment unit. However, the requirement that all the percentages sum to 100 percent becomes a difficult operational problem if several land-entity allocations are each represented by a probability distribution. In the NOGA project, resource allocations are typically made to a number of land entities, and allocation percentages are consequently recorded as point estimates (as modal values) only, the sum of which equals 100 percent.

In this example, the assessment unit is identified as a gas assessment unit, so only gas data are recorded. The lines for oil in oil assessment unit are left blank. Based on our geologic knowledge of the areal distribution of cells having the potential for additions to reserves, and using data derived from GIS, the following information is recorded on the data-input form:

1. Colorado

Oil in oil assessment unit:

Volume $\%$ in entity

Gas in gas assessment unit:

Volume $\%$ in entity

2. Wyoming

Oil in oil assessment unit:

Volume $\%$ in entity

Gas in gas assessment unit:

Volume $\%$ in entity represents

90 area $\%$ of the $\mathrm{AU}$

minimum

mode

maximum
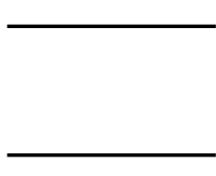

represents

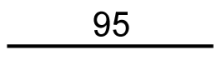

10 area $\%$ of the $\mathrm{AU}$

minimum

mode

maximum 


\section{Conclusions}

The USGS FORSPAN assessment model for continuous petroleum accumulations requires geology- and engineering-based input data. Necessary input data are recorded on the form described in this report, which is completed for each assessment unit of a continuous accumulation. The form consists of seven sections:

- Identification Information.

- Characteristics of Assessment Unit.

- Number of Untested Cells with Potential for Additions to Reserves.

- Total Recovery per Cell.

- Average Co-product Ratios for Untested Cells.

- Selected Ancillary Data for Untested Cells.

- Allocations of Potential Additions to Reserves to Land Entities.

Identification information supplies the data necessary for record keeping and assessment organization. Statistical combination of the minimum total recovery per cell, geologic probabilities (from Characteristics of Assessment Unit), number of untested cells, total recovery per cell, and co-product ratios yields probability distributions for quantities of petroleum having the potential to be added to reserves. Selected ancillary data provide a set of information (not used directly in assessment calculations) that is required for economic and environmental analyses. Allocation percentages allow the apportionment of assessed potential additions to reserves to various land entities of interest within the assessment unit. 


\section{References Cited}

American Petroleum Institute, 1995, Standard definitions for petroleum statistics: Washington, D.C., American Petroleum Institute, 62 p.

Bailey, R.G., 1995, Description of the ecoregions of the United States: USDA Forest Service Miscellaneous Publication No. 1391 (Rev.), Second Edition, 108 p.

Crovelli, R.A., 2000, Analytic resource assessment method for continuous (unconventional) oil and gas accumulations - the "ACCESS" method: U.S. Geological Survey Open-File Report 00-044, $34 \mathrm{p}$.

IHS Energy Group, 2002a [includes data current as of December, 2001], PI/Dwights Plus US Production Data: Englewood, Colo., IHS Energy Group; database available from IHS Energy Group, 15 Inverness Way East, D205, Englewood, CO 80112, U.S.A.

IHS Energy Group, 2002b [includes data current as of December, 2001], PI/Dwights Plus US Well Data: Englewood, Colo., IHS Energy Group; database available from IHS Energy Group, 15 Inverness Way East, D205, Englewood, CO 80112, U.S.A.

Klett, T.R., Ahlbrandt, T.S., Schmoker, J.W., and Dolton, G.L., 1997, Ranking of the world's oil and gas provinces by known petroleum volumes: U.S. Geological Survey Open-File Report 97-463, 1 CD-ROM.

NRG Associates, 2002 [includes data current as of December, 2000], The Significant Oil and Gas Fields of the United States: Colorado Springs, Colo., NRG Associates, Inc.; database available from NRG Associates, Inc., P.O. Box 1655, Colorado Springs, CO 80901, U.S.A.

Schmoker, J.W., 1996, Method for assessing continuous-type (unconventional) hydrocarbon accumulations, in Gautier, D.L., Dolton, G.L., Takahashi, K.I., and Varnes, K.L., eds., 1995 National assessment of United States oil and gas resources--Results, methodology, and supporting data: U.S. Geological Survey Digital Data Series DDS-30, Release 2 (1 CD-ROM).

Schmoker, J.W., 1999, U.S. Geological Survey assessment model for continuous (unconventional) oil and gas accumulations - the "FORSPAN" model: U.S. Geological Survey Bulletin 2168, 9 p.

Schmoker, J.W., 2003, U.S. Geological Survey assessment concepts for continuous petroleum accumulations, in USGS Uinta-Piceance Assessment Team, compilers, Petroleum systems and geological assessment of oil and gas in the Uinta-Piceance Province, Utah and Colorado: U.S. Geological Survey Digital Data Series DDS-69-B, Version 1 (1 CD-ROM) 


\section{Appendix 4 \\ Distribution Types}

\section{Triangular Distributions}

Triangular distributions are used in the FORSPAN model to show the uncertainty about the geologic values on the input form. The triangular distribution is commonly used in probabilistic studies. It has the advantages of being simple to visualize and being easy to describe with only three parameters, minimum, maximum, and a central value (fig. A4-1).

There are three central values that should be distinguished: the mode, median, and mean. The mode is the value for the peak of the distribution; it is the "most likely" value. The median is the value for which there is a 50 percent chance of smaller than that value and a 50 percent chance of larger than that value. The mean is the average value over the entire distribution. For a symmetrical triangular distribution, these three central values are all identical. For an asymmetrical triangular distribution, these three central values are all different.

Given the minimum, the maximum, and any one of the central values, the other central values can be calculated. The relation between the values entered on the input-data form (minimum, mode, and maximum) and mean is given by

$($ minimum + mode + maximum $) / 3=$ mean

Triangular distributions can only accommodate limited skewness. If the mode of the distribution is placed at either the minimum or maximum value, the median will be 0.2929 times the maximum minus the minimum towards the other extreme. Thus the median is constrained to lie within roughly the central 40 percent of the value range (fig. A4-2).

\section{Lognormal Distributions}

Lognormal distributions are used in FORSPAN to model the distribution of EUR values. EUR's, like conventional field sizes, have a very skewed distribution with a few very high values and many low values. Triangular distributions cannot represent these high values of skewness. The distributions are again described using three values: a minimum, a maximum, and a central value (mode, median, or mean) (fig. A4-3).

Regular lognormal distributions have a minimum value of 0 and no maximum value. For a more realistic distribution, the truncated shifted lognormal is used. The distribution is shifted to the right so that the distribution minimum is at the required value rather than 0 . The truncation takes place on the right-hand tail to eliminate the possibility of unreasonably high EUR's. The 0.1 percent fractile is the truncation point. This very small percent keeps the recalculated fractiles close to the original input. 


\section{Conventional and Continuous Accumulations}

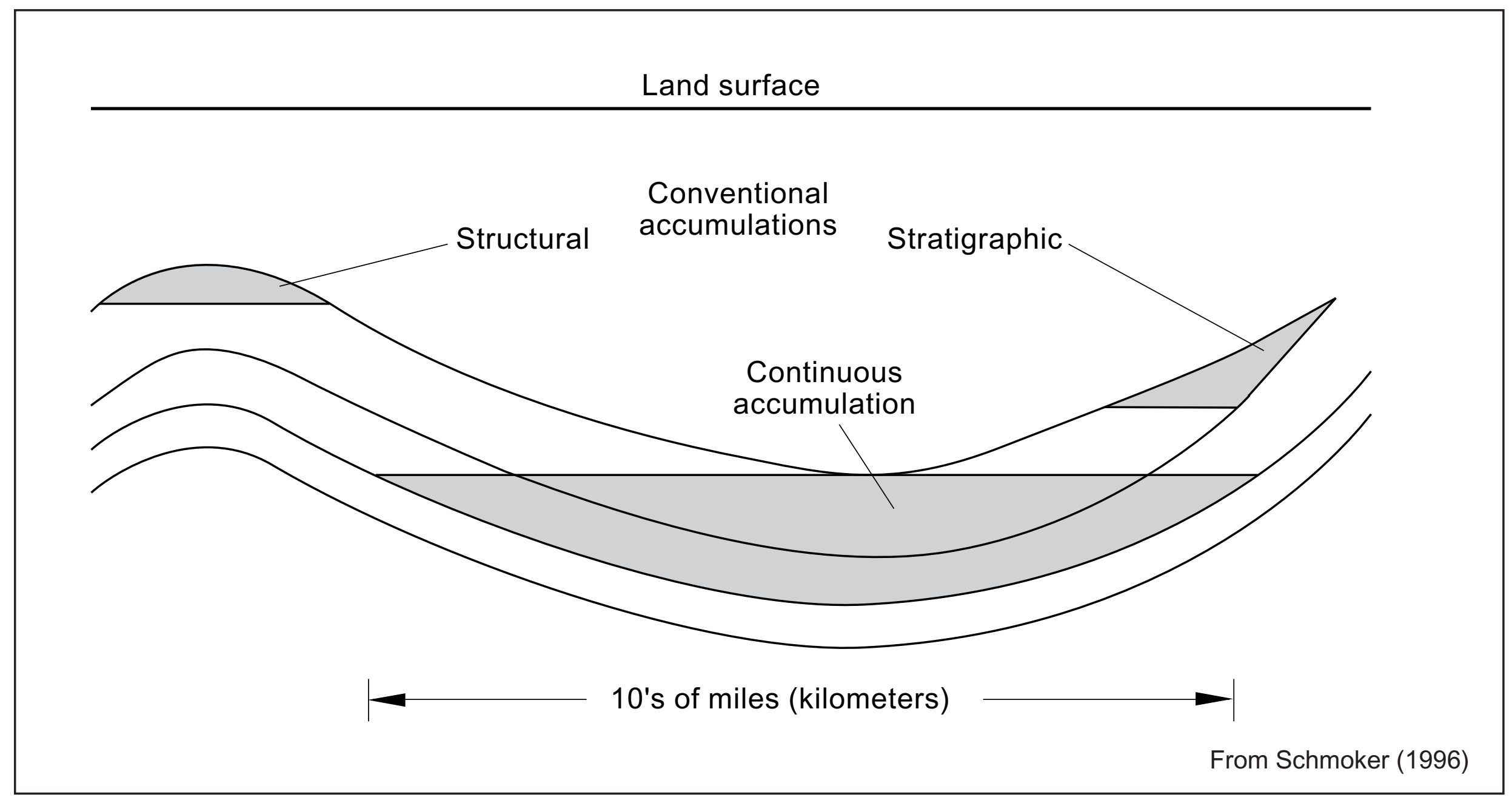

Figure 1. Conventional and continuous accumulations. Conventional accumulations are shown here in anticlines and stratigraphic pinchout traps. Conventional accumulations are defined as discrete accumulations with down-dip water contacts, which are affected by the buoyancy of petroleum in water. Continuous accumulations, also called unconventional accumulations, have large spatial dimensions and lack well-defined down-dip petroleum/water contacts, and therefore are not localized by buoyancy. Continuous accumulations include "tight-gas reservoirs", coalbed gas, shallow biogenic gas, and oil and gas in shale. 


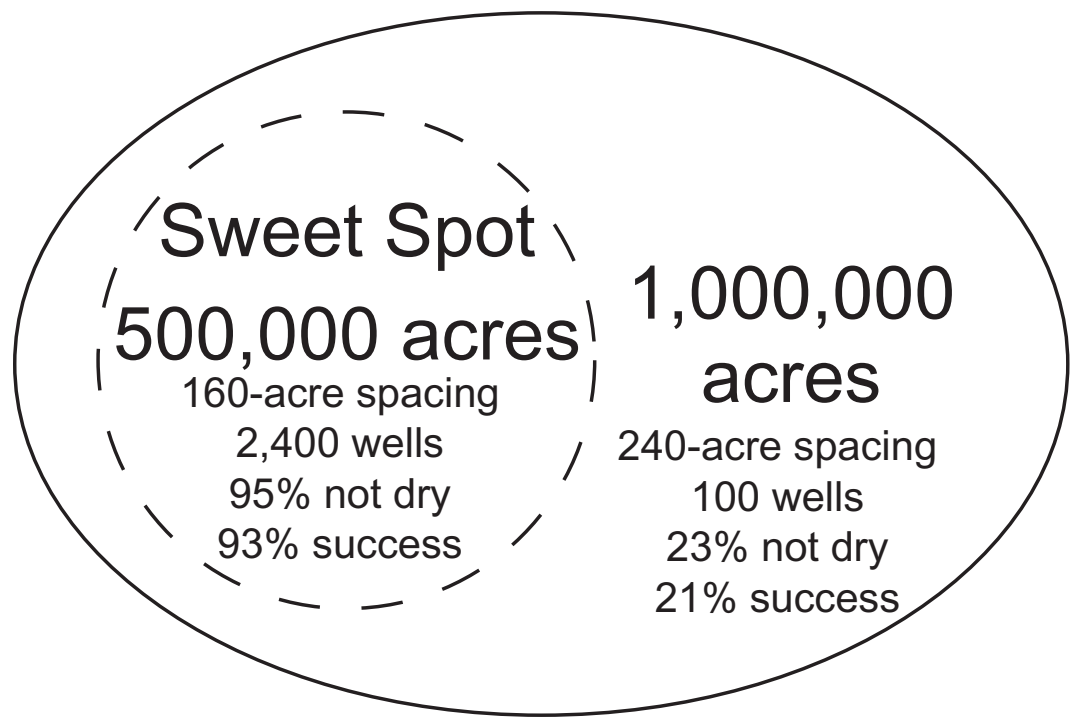

Figure 2. Schematic map of assessment unit with sweet spot and hypothetical values for spacing, number of wells, and success ratio. 


\section{Estimated Ultimate Recovery Distributions}
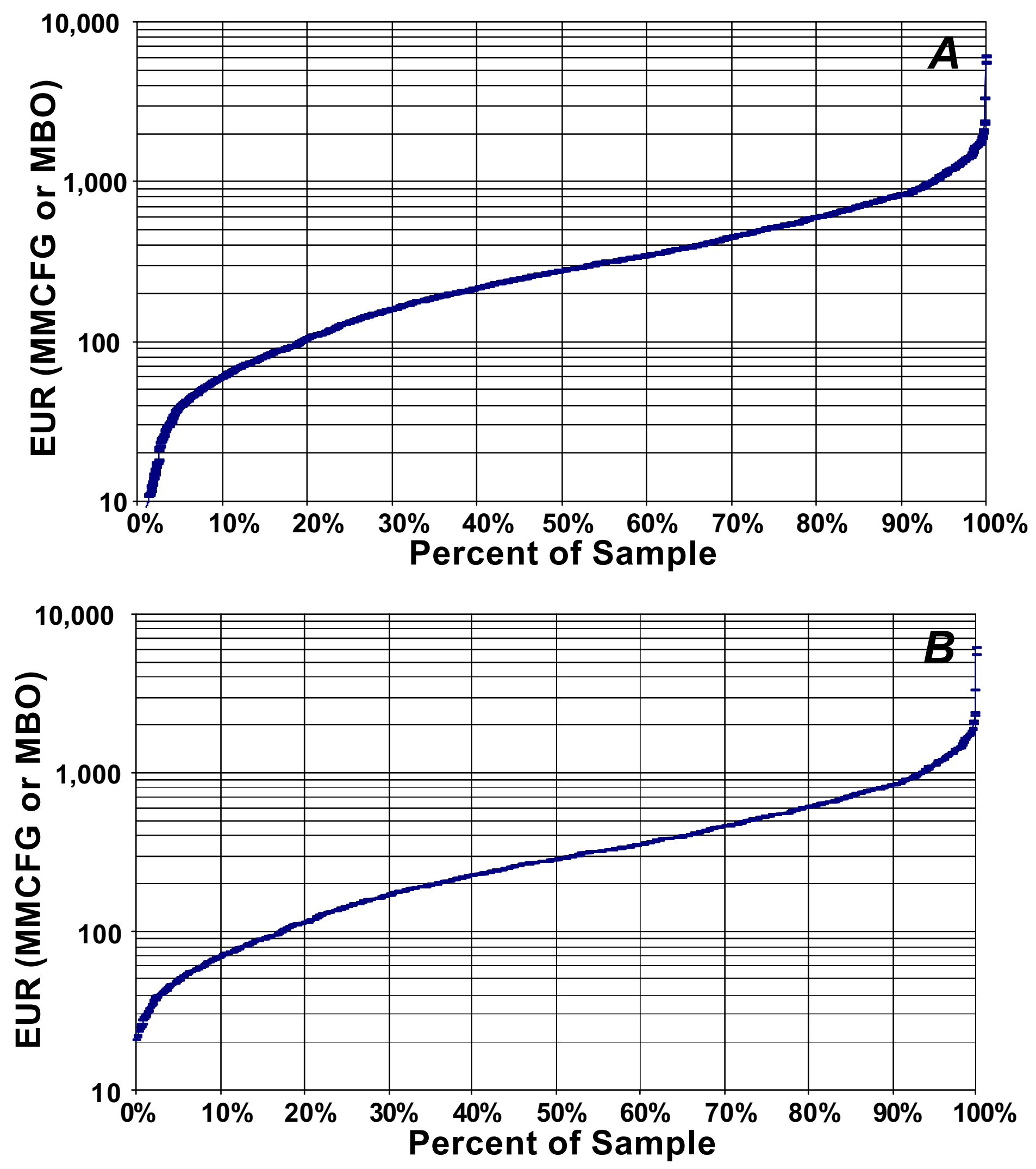

Figure 3. Graphs showing the distribution of EUR's of wells within the assessment unit used to determine the distribution of total recovery per cell. $A$. The distribution of EUR's of all wells in the assessment unit. $B$. The distribution of EUR's of wells greater than or equal to the minimum specified total recovery per cell. 


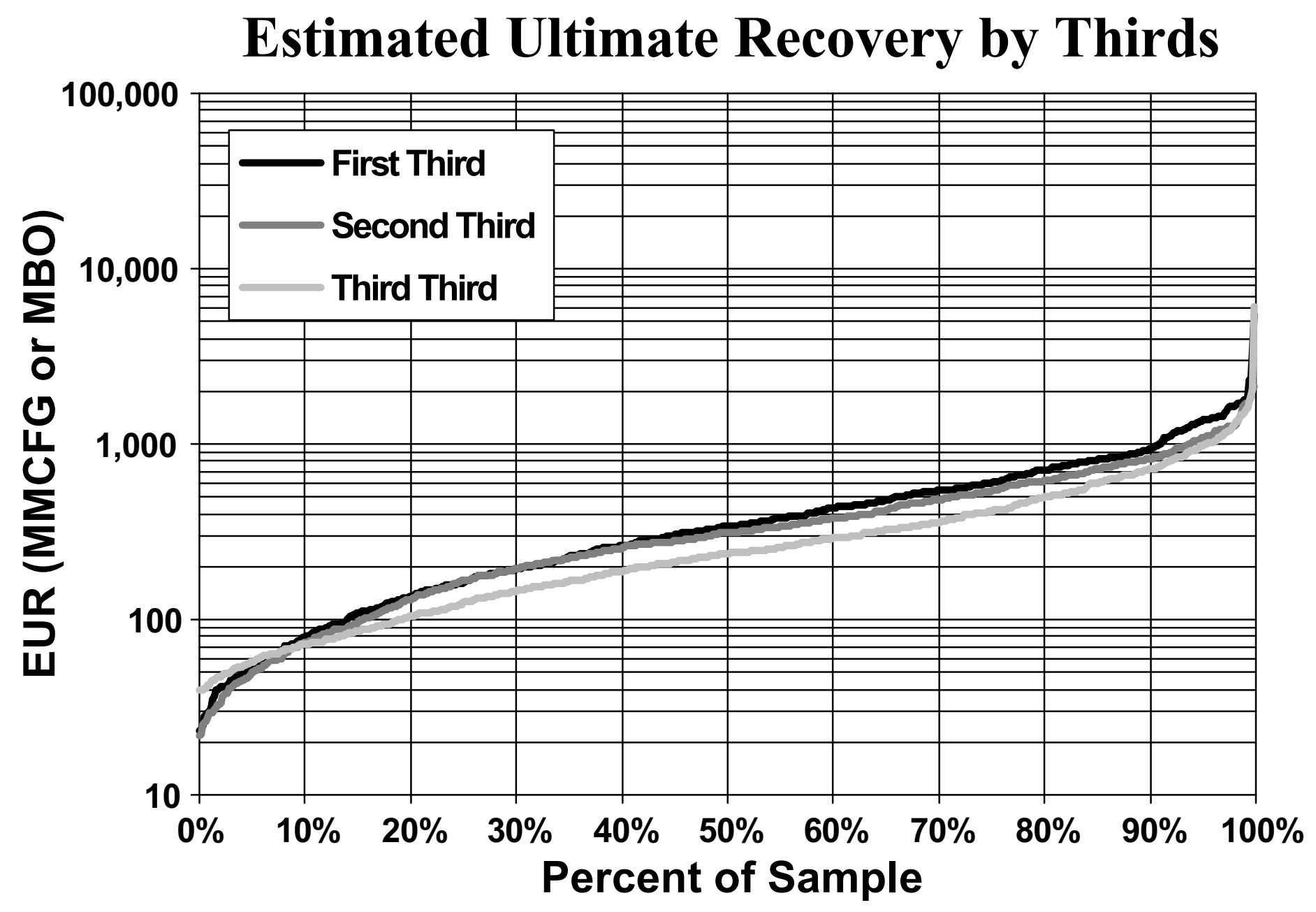

Figure 4. The distribution of EUR's of wells having total recovery per cell greater than or equal to the minimum and divided into the first-third, the second-third, and the third-third of wells drilled. 


\section{Triangular Distributions}

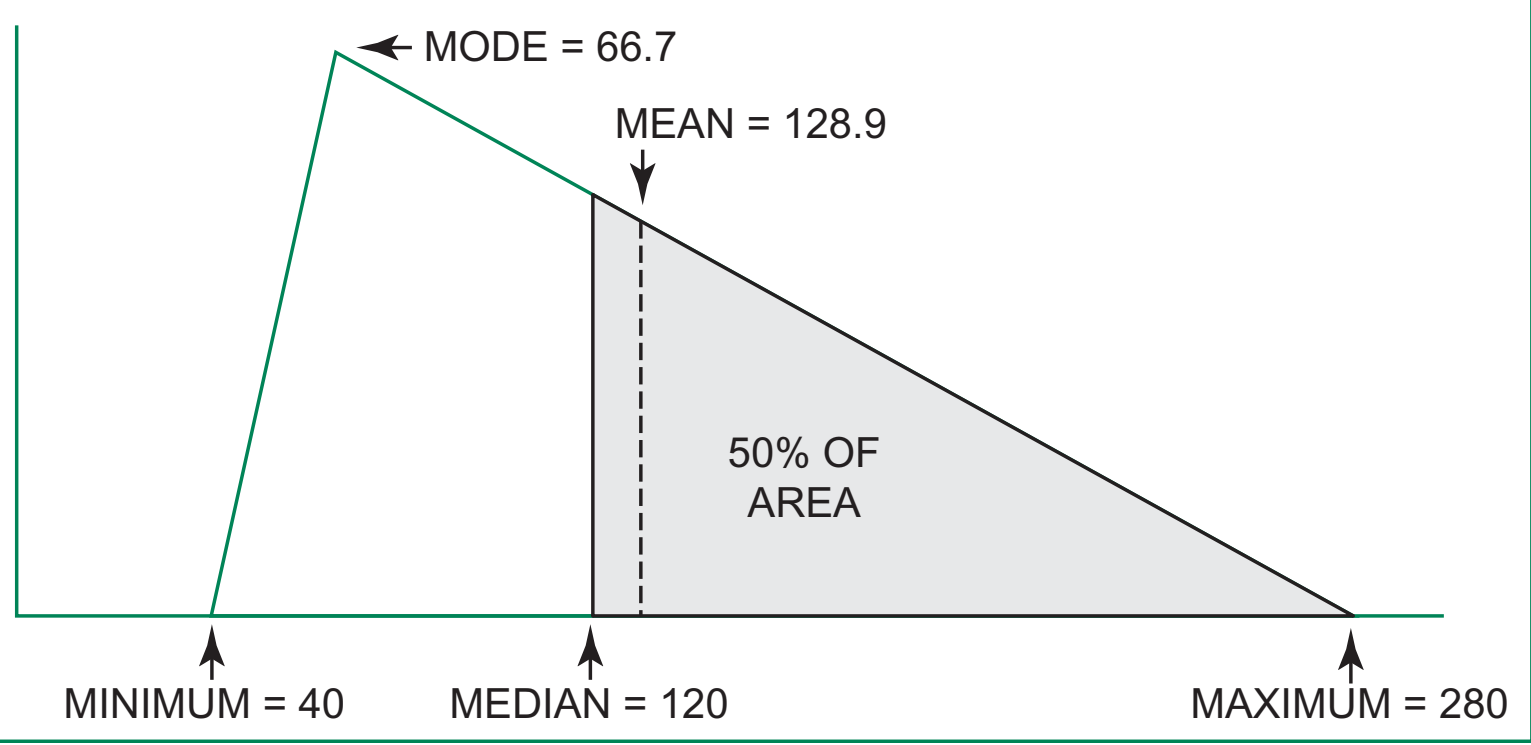

Figure A4-1. Components of a triangular distribution.
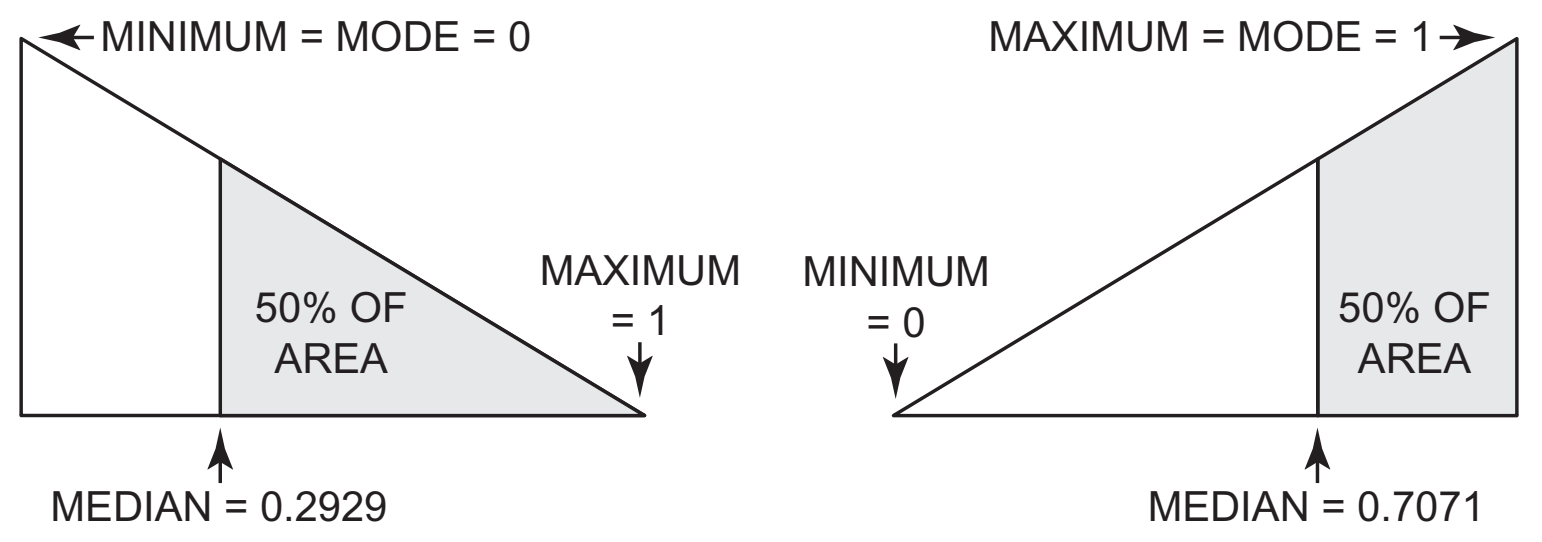

Figure A4-2. Components of two oppositely skewed triangular distributions. 


\section{Lognormal Distributions}

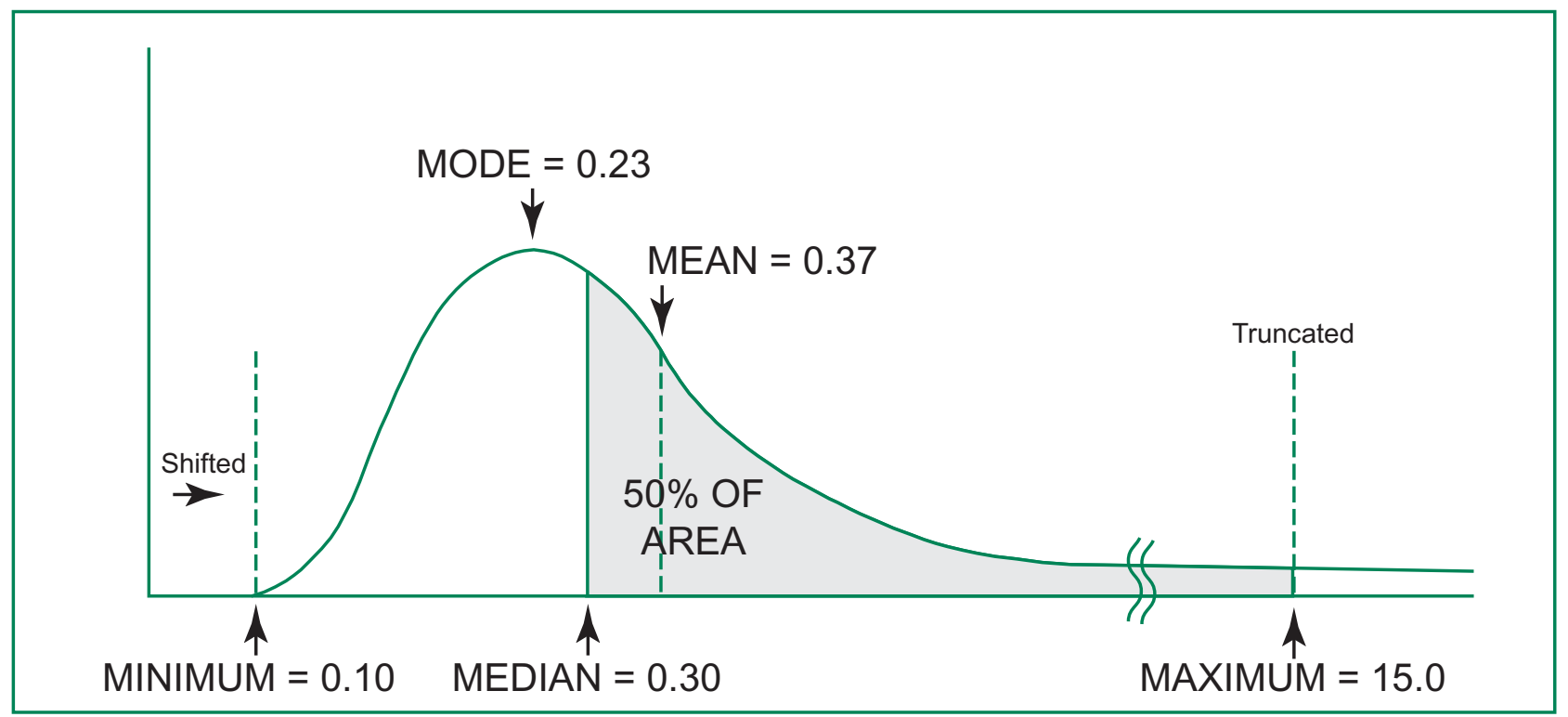

Figure A4-3. Components of a lognormal distribution. 